再発胃癌症例に括ける biological response modifier の

$$
\begin{gathered}
\text { 胸管リンパ球に扣よぼす影響について } \\
\text { 一溶連菌製剤 OK-432の検討一 }
\end{gathered}
$$

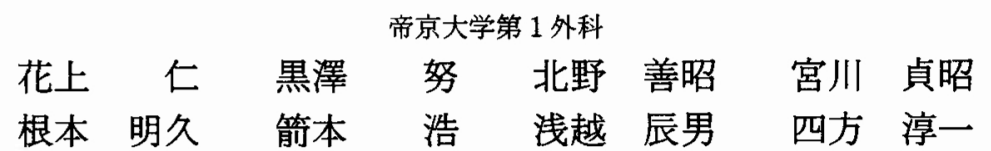

\title{
CLINICAL STUDIES OF BIOLOGICAL RESPONSE MODIFIER \\ ON THORACIC DUCT LYMPHOCYTES IN PATIENTS WITH RECURRENT GASTRIC CANCER WITH SPECIAL REFERNCE TO EFFECT OF STREPTOCOCCAL OK-432
}

\section{Hitoshi HANAUE, Tsutomu KUROSAWA, Yoshiaki KITANO, Sadaaki MIYAKAWA, Akihisa NEMOTO, Hiroshi YAMOTO, Tatsuo ASAGOE and Jun-ichi SHIKATA}

The First Department of Surgery, Teikyo University School of Medicine

再発胃癌 9 例において, 溶連菌製剂 OK-432の免疫療法を行い, 治療前および治療開始後 4 週に胸管 リンパ球 (TDL) と末梢血リンパ球 (PBL) を採取し免疫学的検索を行った，治療前では TDLは PBL に比較し $\mathrm{T} / \mathrm{B}$ 細胞比は高く, $\mathrm{T} \gamma$ 細胞比は有意 $(\mathrm{p}<0.05)$ 亿低く, リンパ球幼若化率は有意 $(\mathrm{p}<0.05)$ に高く, Natural killer 細胞活性は有意 $(\mathrm{p}<0.01)$ に低かった。治療後 4 週では $\mathrm{T} / \mathrm{B}$ 細胞比と $\mathrm{T} \gamma$ 細 胞比は有意の変動を示さなかったが，リンパ球幼若化率は TDL では有意に $(\mathrm{p}<0.05)$ に低下乙 PBL では変化しなかったので両者の間に有意差は認められなかった．Natural killer 細胞活性は両者にお いて有意 $(\mathrm{p}<0.05)$ に増強された。

索引用語：胸管リンパ球, 再発胃癌, biological response modifier, 胃癌免疫療法, 溶連菌製剂

\section{緒 謇}

悪性腫瘍の治療を目的として，宿主と腫瘍の関係を 宿主優位に変換させようとする薬蝺および治療法，す なわち biological response modifier (BRM) の概念 が定着しつつある，現在使用されている免疫療法剂の ほとんどが BRM の範ちゅらに含まれ，その投与によ り担癌生体にじゃっ起される免疫機能の変化が多くの 研究者により検討された，その結果，悪性腫場におけ る臨床免疫学的理解が急速に進み, 担癌生体の正確な 免疫能の把挃が効果的な免疫療法を行う上で重要なこ とが明らかにされた1)21.

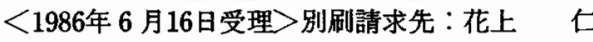
F259-11 伊勢原市望星台 東海大学医学部第 2 外科
担癌生体の細胞性免疫を知るためにさまざまなりン パ球機能検査がなされているが，大部分は末梢血リン パ球（PBL）についてなされているのが現状である。 尰瘍および尰瘍周囲の組織や所属リンパ節内のリンパ 球は，腫瘍免疫において極めて重要な役割をはたして いる3(4) と考方られるが，臨床例に怙いてこれら組織り ンパ球の機能を経時的に検索することは不可能であ る.

一方において，胸管は生体に打いて毛細血管床に匹 敵した容積を有し5), 全身の組織リンパ液を集めたリ ンパ管内リンパが静脈に流入する最終経路である。そ のため胸管リンパ球 (TDL) には組織からリンパ管内 に移行したリンパ球が含まれる6)ので，担癌生体にお いては，腫湯と接触したリンパ球が存在すると考兄ら 
れる、その上，われわれがすでに報告したごとく7，胸 管リンパ液は胸管瘻を作ることにより, 経時的に採取 することができるので, TDLの免疫機能の経時的動態 を知ることが可能である。しかしながら, 胸管瘻造設 術は手術手枝が煩雑なため一般に普及していないの で，臨床例に颃いて担癌状態下の TDL の特性や免疫 療法がTDLに执よぼす影響についての報告は極めて 少ない。

本研究は，BRMに上る非特異的免疫療法を再発胃 癌患者に対して施行し, TDL と PBL の免度学的検索 を行うことにより, TDL と PBL の生物学的特性の差 異ならびに TDL の腫瘍免疫上での意義を解明するこ とを目的として行った。

\section{対象と方法}

胃癌の根治術後再発例 9 例を対象とした。全例男性 で年齢は 46〜 72歳で平均年齢は61歳である。これらの 症例はすべて広範な癌病巣を有するために再手術の適 応外と判断されたものである。

胸管瘦は，局所麻酔下に以前報告した方法7)で作成 し，胸管リンパ液の採取に供した。

BRM として，溶連菌製剤 OK-432（PIC） 1 回に つき5klinische Einheit (KE)，週 3 回皮内投与した。 化学㞠法として, $\mathrm{N}_{1}$ - (2-tetrahydrofuryl)-5fluorouracil (Tegafur) を $800 \mathrm{mg}$, 連日経口投与した。 治療前および治療開始後 4 週において，胸管瘦より 胸管リンパ液と时静脈より血液を同時に採取し，それ ぞれより TDLならびに PBLを分離し， T・B 細胞比, IgG-Fcリセプター陽性 $\mathrm{T}$ （T $\gamma$ ）細胞比, Concanavalin-A (Con-A) 括よび Phytohemagglutinin (PHA) に対するリンパ球幼若化反応，ならびに natural killer （NK）細胞活性を測定した。

$\mathrm{T} \cdot \mathrm{B}$ 細胞比は, $\mathrm{T} \cdot \mathrm{B}$ 細胞測定キット (日本抗体研究 所）を用い測定した。 マイクロプレートゥェル内で, 分離したリンパ球とヒッジ赤血球ならびに補体感作ウ シ赤血球との口ゼット形成を検鏡し，それぞれの口 ゼット形成リンパ球をT細胞ならびにB細胞として, 測定し, $\mathrm{T} ・ \mathrm{~B}$ 細胞比を求めた。

$\mathrm{T} \gamma$ 細胞比は, 新保らの方法 ${ }^{81}$ とて測定した。すなお ち, 形態が特異で $\mathrm{T}$ 細胞との spontaneous rosette formationのないニワトリ赤血球に IgG 抗体を感作し， この赤血球とヒッジ赤血球とを分離したリンパ球に反 応させ, 両者之結合し double rosette を形成するリン 八球を $\mathrm{T} \gamma$ 細胞とし $\mathrm{T}$ 細胞中の百分率を求め $\mathrm{T} \boldsymbol{\gamma}$ 細胞 比とした。
リンパ球幼若化反応は，T細胞に対する mitogen と して PHA (Difco 社) とCon-A (Difco 社)を用いて, 新保ら9の方法を用いて測定した。リンパ球 $5 \times 10^{5}$ 個を 培養テェーブ（Falcon 2054または2058）にとり，培養 液 $1 \mathrm{ml}$ に浮遊し, PHA $100 \mu \mathrm{g} / \mathrm{ml}$ をなは Con-A $10 \mu \mathrm{g} /$ $\mathrm{ml}$ を加えた。をたいずれの mitogen も加えないもの も用意した. $37^{\circ} \mathrm{C}, 5 \% \mathrm{CO}_{2}$ 濃度下で, 70 時間培養後に 各テェーブに ${ }^{3} \mathrm{H}$-thymidine $2 \mu \mathrm{Ci}$ を加光 2 時間培養し た後, 細胞を回収しシンチレーションカウンターにて 放射性活性を測定した. mitogenに対する反応性の評 価は mitogen 添加時の測定値と非添加時の測定値の 比,すなわち stimulation index（SI）によった。

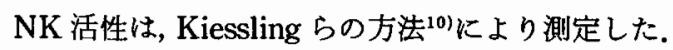
分離したリンパ球を $20 \% \mathrm{FCS}$ 加 RPMI-1640にて5× $10^{6}$ 個 $/ \mathrm{ml}$ に調整した。標的細胞には，七ト白血病細胞 由来の株化細胞 $\mathrm{K} 562$ を用いた。 $\mathrm{K} 562 \mathrm{~K}^{51} \mathrm{Cr}\left(\mathrm{Na}_{2}{ }^{51}\right.$ $\mathrm{CrO} 4,3 \mathrm{mCi} / 3 \mathrm{ml}$, 日本アイントープ協会）を加えて標 識した後, $10 \%$ FCS 加 RPMI-1640にて $2.5 \times 10^{5}$ 個 $/ \mathrm{ml}$ に調整した。標的細胞 $1 \times 10^{4}$ 個に effector 細胞を $5 \times$ $10^{5}$ 個加兄，4 時間培養した後, 以下の式に従い\%lysis を算出し，NK細胞活性とした。

NK 細胞活性 $=$ (experimental ${ }^{51} \mathrm{Cr}$-release)/ (maximum ${ }^{51} \mathrm{Cr}$-release-spontaneous ${ }^{51} \mathrm{Cr}$-release).

測定值の統計学的解析には, student の $\mathrm{t}$ 検定を用 いた.

\section{成 績}

$\mathrm{T} ・ \mathrm{~B}$ 細胞比についてみると, TDL は PBL に比較し

図 1 T·B 練胞比

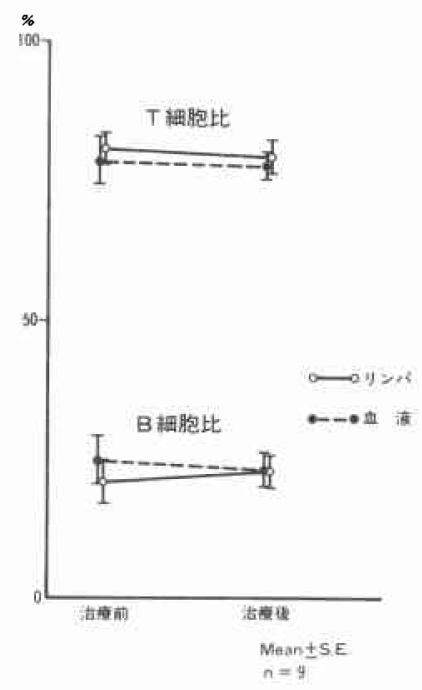


図 $2 \mathrm{~T} \gamma$ 細胞比

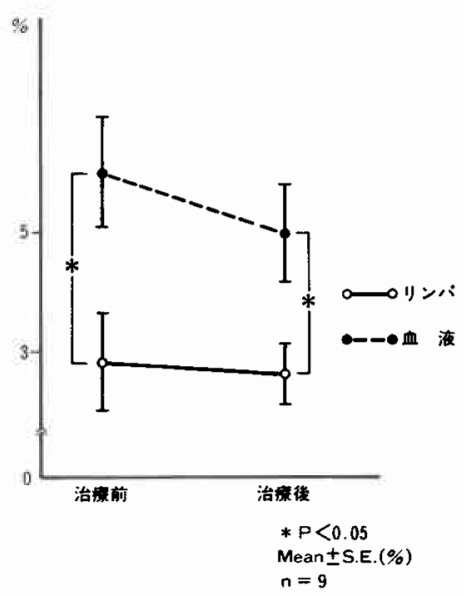

図 3 リンパ球幼若化反応 (Concanavalin-A)

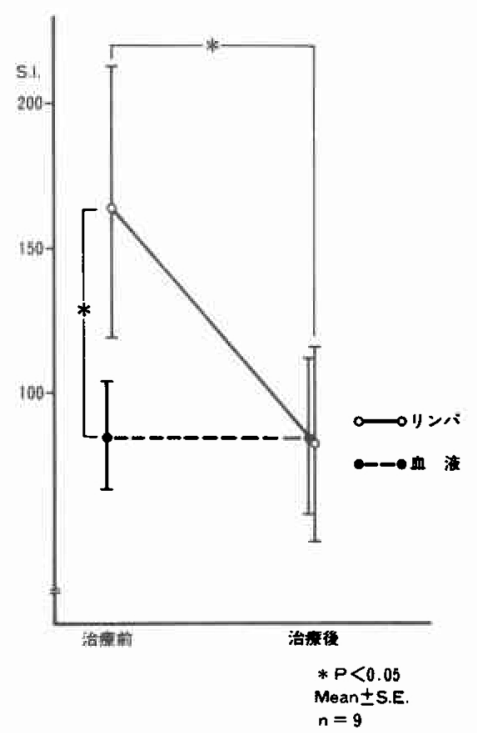

T細胞比は高く B 細胞比は低い傾向を示した.TDL と PBL の両者に颃いて, PIC 投与による有意の変動は認 められなかった（図1）。

$\mathrm{T} \boldsymbol{\gamma}$ 細胞比についてみると, TDL は PBL に比較し 有意に低かった，TDL と PBLの両者に拈いて，PIC 投与による有意の変動は認められなかった（図 2).

Con-AならびにPHA に対するリンパ球幼若反応 についてみると, PIC 投与前では TDL が PBL に比較 し有意に高いSI を示した. PIC 投与開始後 4 週では， 投与前に比較し PBLのSI が明らかな変動を示さな かったのに対し，TDLのSIは有意に低下しており，
図 4 リンパ球奻若化反応 (Phytohemagglutinin)

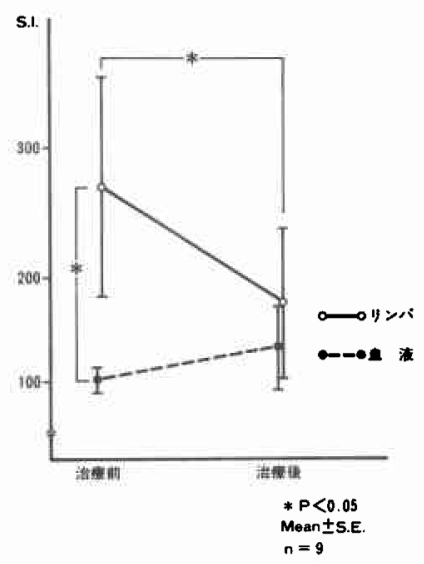

図 5 Natural Killer 細胞活性

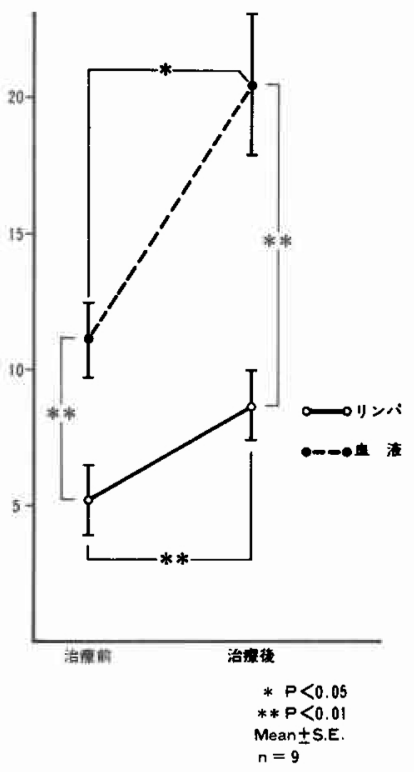

両者の間には有意の差は認められなかった(図 3，4).

NK 細胞活性についてみると, TDL は PBL に比較 し有意に低かった．PIC 投与後 4 週では，投与前に比 較し TDL と PBLの両者において NK 細胞活性は有 意に上昇した（図5）.

PICによる免疫療法の効果についてみると，NK 細 胞活性がTDL および PBL において，上昇しているこ とから，本症例に拈いては免疫賦活効果が得られたも のと思われた。

考察

悪性腫瘍患者における胸管リンパの重要性は, 1798 
年にCooper ${ }^{11)} よ り$ 初めて指摘された。初期において はVirchow ${ }^{12)}$ により胃癌症例に扔いて左鎖骨上窝り ンパ節転移がしばしば見られることが報告されて以 来，胸管は悪性腫湟のリンパ拉よび血行性転移の経路 として興味を集めていたが，近年の臨床兔疫学の進歩 に伴い葴器移植や自己免疫疾患に和ける免疫抑制の手 段 ${ }^{13)}$ 中，担癌患者の免疫能をモニタ一する場 ${ }^{14)}$ として 注目されるに至った。

一方，PICは丹毒を併発した肉腫患者に颃いて腫瘍 が退縮したと言う報告に基づき，Okamoto ら streptolysin-S を産生しない溶連菌製剂として開発し た免疫賦活郕である.PIC は in vitroにおいて腫煬細 胞之混合させると接触した腫煌細胞が壊死すること ${ }^{16)}$ から，当初は通常の制癌剂と同様に直接細胞障害を示 寸薬剤と考兄られていた。しかしその後の研究から， PIC が担癌宿主の免疫担当細胞を介して抗腫瘍効果を 発現していることが明らかにされて以来17118)，BRM として広くわが国において使用されるに至った。

われわれは, 進行消化器癌患者に対して, PICの皮 内投与を行っておりその担癌宿主に招ける免疫能賦活 や生存期間の延長 ${ }^{19}$ についてはすでに報告した。本研 究では, TDL と PBL の生物学的特性と PIC 皮内投与 による影響の差異について臨床免疫学的検討がなされ た。

TDL は PBL に比較し $\mathrm{T}$ 細胞比は高く B 細胞比は

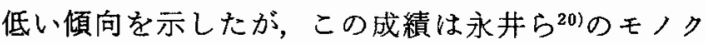
ローナル抗体を用いた成績ともほぼ一致する.TDLの 中には血液から組織へ遊走しリンパ組織内に再循環し ているッンパ球汭の活かに, 相当数の large lymphoid

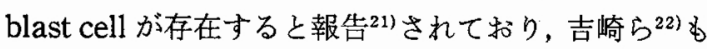
TDL 中に PBLでは見られない末熟な T細胞を電顕 的検索により証明している. TDL と PBLの T・B 細 胞比の差は，このような末梢血には見られないリンパ 球がTDLに含なれていることに起因すると考古られ る。

$\mathrm{IgG}$ 分子の Fc 部に対するリセプターは, マクロ ファージやB $\mathrm{B}$ 細胞のみならず一部の $\mathrm{T}$ 細胞の表面にも 存在し, $\mathrm{T}$ 細胞の機能の一部を担当する $\mathrm{T}$ 細胞サブ セット，すなわち cytotoxic effector や supressor の 性格を持つT細胞との相関が考兄られている ${ }^{8)} . \mathrm{T} \gamma$ 細 胞の局在についてみると, 板垣 ${ }^{23}$ によれぱ PBLに比 較し脾に有意に多くまた転移陰性リンパ節に有意に少 なく存在した. $\mathrm{T} \gamma$ 細胞の増加には, 脾と血清が関与し ていると考号られて括り, 正常者のT細胞を胃癌患者
血清で培養すると IgG-Fc リセプターの増加が認めら れている23).われわれの成績では, TDLの $\mathrm{T} \gamma$ 細胞比 はPBLのそれに比較し有意に低かったが，乙れは永 井ら 20)の成績と一致する。これには, TDLが胸腺やり ンパ節リンパ球に近い特性を持つこと, 癌患者血清中 のサブレッサー活性を誘導する物質がリンパ液中には 少ないこと，ならびに TDLには末分化なT細胞が多 く含まれていること，などが原因として考兄られる.

TDLおよび PBLに拈ける $\mathrm{T} ・ \mathrm{~B}$ 細胞比ならびに $\mathrm{T} \gamma$ 細胞比は PIC 投与によっても有意の変動を示さな かった，われわれのこの成績は，PIC 投与により $\mathrm{T}$ 細 胞系免疫能の改善を認めた Uchida ら ${ }^{18)}$ の報告と異な る.これは Uchida ら ${ }^{18)}$ の症例は, 大部分腫瘍の進展が 所属リンパ節に止どまっているのに対し，われわれの 症例は再発例なので, より広範囲に腫煬が浸潤してい るため, 宿主免度能の荒廃は高度であり, PIC 投与は 病期の進行による 活するにはいたらなかったためと考兄られる。

Con-A および PHA に対する SI では, TDL が PBL に比較し高值を示した。 Benninghoff ら ${ }^{24)}$ る同様の報 告をしており,TDLにT細胞が多いことによるとして いる.われわれの成績でも，TDLのT細胞比は PBL に比較し高かったが Benninghoff ら4)の成績汪どそ の差は顕著でないので, TDL 差はそれぞれに含まれる 細胞数のみでなく成熟度や リンパ球幼若反応と負の相関をもつ $\mathrm{T} \gamma$ 細胞比 ${ }^{25)}$ 差 にもよっていると考觉られる。

PIC 投与により，PBLのSIは有意の变動を示さな かったが TDLの SI は低下した. PHA と Con-A によ るリンパ球幼若化反応は T細胞機能の指標であり，癌 患者に招いてその進行に従った低下が知られてい る ${ }^{26)}$.われわれの症例において PIC 投与中に, TDL と $\mathrm{PBL}$ の $\mathrm{T}$ 細胞比, $\mathrm{T} \gamma$ 細胞比, ならびに PBL の SI が 維持されているのにもかかわらず TDLの SI が低下 したことは， T 細胞機能の障害は初期においてまず TDLに出現することを示唆していると考えられる。こ のことから腫崲免度において重要な役割を果している T細胞機能の变動を早期にとらえるためには, TDLの 検索が極めて有用であると考学られる。

NK 細胞 ${ }^{271}$ は, ヒト，ラット，およびマウスなどで何 ら前感作なしに腫瘍細胞を破壊するリンパ球である が，その effector cell の性格については議論の多いと ころである。ヒッジ赤血球とロゼットを作らず，表面 免度グロブリン陰性, かつ IgG-Fcリセプタ一陽性の 
リンパ球，つまり null cell 系の細胞であると言う報 告28)が多かったが, IgG-Fcリセプター陽性T細胞にも

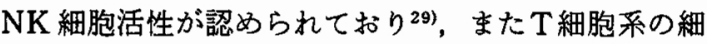
胞であると言う報告30)もる。 TDLの NK 細胞活性 はPBLに比較し有意に低かったが，これはTDLに null 系細胞や $\mathrm{T} \gamma$ 細胞が少ないことによると思われる が，TDLに末熟なリンパ球が多いため分化が十分に行 われていないこともその原因として考克られる。

PICは，インターフェロン(INF)やインターロイキ ン(IL)-2などのリンフオカインを誘起し，これらを介 してNK 細胞活性を増強する31132). 本研究において も，TDL と PBL の両者に扑いて PIC 投与により NK 細胞活性は有意に増強された。 PIC 投与により， T細 胞系免疫能が増強されえないほど進行した再発胃癌患 者においてさえも，NK 細胞活性が有意に増強された ことは, NK 細胞活性を持つ effector cell の PIC に対 する感受性が免疫能の低下した担癌患者においてす保 持されていることを示するのと考えられる。

以上のごとく，TDLと PBLはさまざまな点で異 なった生物学的特性を持つことが明らかにされた。特 に，T細胞の機能障害が TDLにおいてほかにさきが けて感知されたことは, 癌免疫療法においては TDL の積極的な検索が必要であることを示唆するすのと考 えられる。

\section{結語}

PICによる非特異的免疫療法を受けた 9 例の再発胃 癌患者において治療前後に TDLならびに PBLの免 疫学的検索を行い以下の結論を得た。

1) TDL は PBL に比較し。T細胞比は高く $\mathrm{B}$ 細胞 比は低かったが，両者に扔いて PIC 投与により有意の 変動は認められなかった。

2) TDLはPBLに比較し， T $\boldsymbol{y}$ 細胞比は有意に低 かったが, 両者に打いて PIC 投与により有意の变動は 認められなかった。

3）TDLはPBLに比較し，リンパ球幼若化反応の SI は治療前では有意に高値を示したが, 治療後では SI はTDLで低下しPBLでは有意に変動しなかったの で両者のSI には有意の差は認められなかった。

4）TDLは PBL K比較し，NK 細胞活性は有意に 低かったが PIC 投与により両者の NK 細胞活性は上 界した。

5）以上により，TDLと PBL の生物学的特性はさ まさまな点で異なっており，特に丁細胞機能障害が PBLより TDLにおいてょり早期に感知されている
ことは, 癌免疫療法に扮ける TDL の積極的な検索の 重要性を示唆するすのと考学られた。

\section{文献}

1) Hanaue $H$, Nomoto $S$, Kimura $T$ et al: Immunological parameters in gastric cancer patients treated with immunotherapy of streptecoccal preparation OK-432. Keio J Med 31 : 159-168, 1982

2) Hanaue H, Yoshizaki S, Kurosawa $T$ : Reevaluation of immunological parameters in immunotherapy for advanced carcinoma of the digestive tract. Gastroenterol Jpn 18 : 377-383, 1983

3) Watanabe $S$, Sato $Y$, Kodama $T$ et al: Immunohistochemical study with monoclonal antibodies on immune response in human lung cancers. Cancer Res $43: 5883-5889,1983$

4) Fisher B, Saffer E, Fisher ER: Studies concerning the regional lymph node in cancer. IV. Tumor inhibition by regional lymph node cells. Cancer $33: 631-636,1974$

5) Abell JJ, Hampil B, Jonas AF et al: Researches on tetanus. VII. Bull Johns Hopkins Hosp $62: 522-563,1938$

6) Gowans JL: The re-circulation of lymphocytes from blood to lymph in the rat. J Physiol 146: 54-69, 1959

7) Hanaue $H$, Kurosawa $T$, Kitano $Y$ et al: $\mathrm{N}$-(2-tetrahydrofuryl)-5-fluorouracil (FT-207) in the postoperative adjuvant chemotherapy of gastric cancer. Cancer $57: 693-698,1986$

8）新保敏和, 矢田純一, 中川俊郎ほか：ヒト IgGFcreceptor 陽性 T リンパ球の検出法と各種疾患 に拈ける変動。臨免疫 $9: 141-145,1977$

9）新保敏和, 麦谷暒夫, 菅原真智子ほか：癌患者にみ られるリンバ球とマクロフォージの異常. 癌と化 療 $5: 261-271,1978$

10) Kiessling R, Klein E, Wigzell $\mathrm{H}$ : "Natural Killer cells in the mouse". I. Cytotoxic cells with specificity for mouse moloney leukemia cells. Specificity and distribution according to genotype. Eur J Immunol 5 : 112-117, 1975

11) Cooper A: Three instances of obstruction of the thoraciduct, with some experiments, showing the effects of typing the vessel. London, Med Rec Private M Assoc, 1978, p86-115

12) Virchow $R$ : Zur diagnose der krebse in unterliebe. Med Reform $45: 248,1848$

13) Starzl TE, Weil R, Koep LJ et al: Thoracic duct drainage before and after cadaveric kidney transplantation. Surg Gynecol Obstet 149 : 
815-821, 1979

14) Girardet RE, Benninghoff DL, Ransdell HT: Technic of chronic throacic duct "Side Fistula" for immunologic evaluation of patients with cancer. Am J Surg 130: 97-101, 1975

15) Okamoto H, Minai $M$, Shoin $S$ et al: Experimental anticancer studies. Part XXXI. On the streptococcal preparation having potent anticancer activity. Jpn J Exp Med 36 : 175-186, 1966

16) Lirplawa $T$, Hattori $T$, Furue $H$ : Clinical experience with streptococcal anticancer preparation OK-432. (NSC-B 116209). Cancer Chemother Rept $56: 211-220,1972$

17) Ishii $Y$, Yamaoka $H$, Toh $K$ et al: Inhibition of tumor growth in vivo and in viyro ny macro. phages from rats treated with a streptococcal preparation, OK-432. Gann 67:115-119, 1976

18) Uchida A, Hoshino $T$ : Clinical studies on cell-mediated immunity in patients with malig. nant disease : I. Fefects of immunotherapy with OK-432 on lymphocyte subpopulation an dphytomitogen responsiveness in vitro. Cancer $45: 476-483,1980$

19) Hanaue $H$, Kurosawa $T$, Yoshizaki $S$ et al: Efficacy of streptococcal preparation OK-432 for gastric cancer patients-comparison between intradermal and intramuscular injection. Jpn J Surg $14: 191-197,1984$

20）永井研治, 松本純夫, 杉本辰男ほか：胃癌患者にお けるヒト胸管リンパ球の腫場認識と Interleukin2 による Killer 細胞誘導の検討. 日消外会誌 $19: 12-18,1986$

21) Heath TJ, Lascelles AK, Morris B: The cells of sheep lymph. J Anat 96:397-403, 1962

22）吉崎 聰, 笠原正男：胸管リンパに上る胃湂診断 及び治療上の意外科診療 $24: 1797-1808$, 1982
23）板桓衛治：胃癌患者に括けるIgG-Fcリセプター 陽性 $\mathrm{T}$ 細胞の意義に関する基礎的並びに臨床的 研究。 日外会誌 $86 ： 1405-1416,1985$

24) Benninghoff DL, Girardet RE, Porteous DD: Thoracicduct and blood lymphocytes in cancer. Lancet $2: 264-265,1973$

25）滝 正憲：消化器癌患者に括けるIgG-Fcリセプ タ一陽性 T細胞の検討. 日癌治療会誌 17 ： $720-727,1982$

26）田口公晴, 前田廸郎, 岸本宏之ほか：胃癌術後成績 と組織反応拉よびこれと免度バラメーターとの関 連. 癌の臨 25:1389-1395, 1979

27) Takasugi M, Mickey MR, Terasaki PI : Reactivity of lymphocyte from normal person on cultured tumor cells. Cancer Res 33 : 2898-2902, 1973

28) Shellan GR: Gross-virus-induced lymphoma in the rat. V. Natural cyyoyoxic cells are non-T cells. Int J Cancer 19:225-235, 1977

29) West WH, Cannon GB, Kay HD et al: Natural cytotoxic reactivity of human lymphocytes against a myeloid cell line : Characterization of effector cells. J Immunol 118 : 353-361, 1977

30) Kay HD, Bonnard GD, West WH et al: A functional comparison of human Fc-receptorbering lymphocytes active in natural cytotoxicity and antibody-dependent cellular cytotoxicity. J Immunol 118 : 2058-2066, 1977

31) Saito M, Ebina T, Koi $M$ et al : Induction of interferon- $\gamma$ in mouse spleen cells by OK-432, a preparation of streptococcas pyogenes. Cell Immunol 68 : 187-192, 1982

32) Wakasugi $H$, Kasahara $T$, Minato $N$ : In vitro potentiation of human natural killer cell activity by a streptococcal preparation, OK-432: Interferin and interleukin-2 participation in the stimulation with OK-432. J Clin Immunol 69 : 807-812, 1982 